\title{
EVALUATION OF THE TOTAL FLUORIDE INTAKE OF 4-7-YEAR-OLD CHILDREN FROM DIET AND DENTIFRICE
}

\author{
AVALIAÇÃO DA INGESTÃO TOTAL DE FLÚOR DE CRIANÇAS ENTRE 4 E 7 \\ ANOS DE IDADE ATRAVÉS DA DIETA E DENTIFRÍCIO
}

\author{
Juliano Pelim PESSAN \\ DDS, Graduate student, Bauru School of Dentistry, University of São Paulo. \\ Salete Moura Bonifácio da SILVA \\ DDS, PhD, Assistant Professor, Bauru School of Dentistry, University of São Paulo. \\ Marília Afonso Rabelo BUZALAF \\ DDS, PhD, Associate Professor, Bauru School of Dentistry, University of São Paulo.
}

\begin{abstract}
$T$ his study measured the total daily fluoride (F) intake of 21 children, living in Bauru, a fluoridated community. F intake from diet (D) and dentifrice (B) was determined for 2 groups of children: A (4-5-year-old) and B (6-7year-old). The method of 24-hour duplicate diet was used. F ingested from dentifrice was indirectly obtained, subtracting the amount expelled and the amount left on the toothbrush from the amount initially loaded onto the brush. F analysis was carried out with the ion specific electrode (Orion 9409), after hexamethyldisiloxane-facilitated diffusion. The amount of $\mathrm{F}$ intake from $\mathrm{D}$ and $\mathrm{B}$ was divided by the child weight and total intake (T) was calculated by adding D and B. Data were analyzed by Student's " $t$ " ( $p<0.05)$ test and by linear regression. Results (mean \pm $\mathrm{SD}, \mathrm{mg} \mathrm{F} / \mathrm{Kg}$ body weigh) of T, D and B were, respectively: $0.056 \pm 0.040 ; 0.018 \pm 0.12 ; 0.037 \pm 0.038$ for all children; $0.055 \pm 0.026 ; 0.021 \pm 0.014 ; 0.034 \pm 0.027$ for Group A and $0.057 \pm 0.052 ; 0.016 \pm 0.010 ; 0.041 \pm 0.046$ for Group B. There was a strong positive correlation between the amount of dentifrice used and the amount of fluoride ingested $(\mathrm{r}=0.92, \mathrm{p}<0.0001)$. One-third of the children analyzed were exposed to a F dose above $0.07 \mathrm{mg} / \mathrm{Kg}$ body weight, which is recommended as the upper limit of daily F intake. Dentifrice was the main source of F ingested by children with percentages of $57.43 \pm 29.02$ for all children; $56.49 \pm 31.82$ for group A; and $58.29 \pm 27.78$ for group B. No significant differences were found between the 2 groups.
\end{abstract}

UNITERMS: Fluoride; Dental fluorosis; Dentifrice; Diet.

\section{INTRODUCTION}

The effectiveness of fluoridated dentifrices for dental caries reduction is well established in the literature. It is known that the main cariostatic effect of fluoride (F) occurs by its topical action, reducing demineralization and enhancing remineralization of the enamel ${ }^{18}$.

Recent investigations have confirmed the safety of $F$ in relation to human health, when used as recommended for caries control ${ }^{23}$. However, it is known that the earliest clinical sign of chronic excessive ingestion of $\mathrm{F}$ by young children is dental fluorosis, the prevalence of which has been increasing in the last half of the twentieth century ${ }^{6}$. The critical period of exposure for all permanent teeth is between 11 months and 7 years of age ${ }^{10}$. Excessive $F$ intake by peoples older than 7 years will not cause dental fluorosis.

Some studies have shown the importance of knowing the amount of $\mathrm{F}$ present in foods ingested by children because dental fluorosis is a systemic effect caused by excessive $\mathrm{F}$ ingestion. It is important, therefore, to take into account all sources that may contribute to the total intake of this ion. Buzalaf et $\mathrm{al}^{5}$ analyzed infant foods and drinks and concluded that some of them are potential risk factors for the development of dental fluorosis. 
A recent literature review emphasized that powdered milk is considered a risk factor for dental fluorosis, mainly in fluoridated areas, due to the use of fluoridated water to reconstitute it ${ }^{4}$.

However, the most important risk factor for dental fluorosis is the amount of fluoride ingested from all sources, that could exceed the upper limit of the ranges of estimates believed to be associated with increased risk of dental fluorosis $(0.07 \mathrm{mg} \mathrm{F} / \mathrm{Kg}$ body weigh/ day) $)^{4,14}$.

For the estimative of fluoride intake from the diet, more accurate data can be obtained if duplicate samples of foods and beverages that were actually consumed are collected and analyzed. An estimative of fluoride intake from dentifrice may be obtained as well ${ }^{9}$. There are some reports in the literature using these estimates, but most of them were based on 2-3year-old children, because of the risk of dental fluorosis on the permanent central incisors ${ }^{2,9,13,21}$. For children aging 4-7 years old, there are only two reports in the literature on the fluoride intake from the diet, but they did not use the method of duplicate diet ${ }^{3,15}$. In addition, there is a lack of data for Brazilian children considering this age range.

The aim of the present study was to evaluate the $\mathrm{F}$ intake of 21 4-7-year-old children, living in a fluoridated community, through diet and dentifrice which are the main sources of $F$ intake.

\section{MATERIAL AND METHODS}

\section{Volunteers}

Twenty-one children, attended at the Pedodontics Service of Bauru School of Dentistry - University of São Paulo, took part in this study, which was approved by the local Ethical Committee. They were divided into 2 groups: Group A, having 10 4-5-year-old children and Group B, having 11 6-7-year-old children (Group B). All the children lived in a fluoridated area (Bauru, 0.6-0.8 ppm), had good oral health and were not using medicines. Children that had focal infections, residual roots or many cavity lesions did not participate.

\section{Collection of duplicate diets}

To determine fluoride intake from diet, the method of 24-hour duplicate diet was used. This procedure, as well the estimation of $\mathrm{F}$ intake from dentifrice, was done only at one time, because diet and toothbrushing habits may be considered relatively constant ${ }^{7}$.
Instructions for collecting foods and drinks were given to the parents of the children, as described by GuhaChowdhury et al. ${ }^{9}$. The parents were instructed to keep the usual diet habits of their children and to duplicate the diet as precisely as possible by observing the amounts that the children had really eaten and drunk. Parents were requested to remove parts of foods not normally eaten, such as seeds, cores, skin, and bones, before including the food in the container.

Parents were asked to use household measures, such as teaspoon, table spoon, or cupsful, to approximate quantities of food ingested. In the case of cooked meals, parents were asked to serve 2 similar portions on 2 separate plates, to wait until the children had finished their portion, and to add or remove comparable portions on the separate plate. In addition to collecting duplicate diets, parents were also requested to maintain a 24-hour diet record of all foods and drinks ingested by the children.

Appointments were scheduled for the day after the diet collection. At this time, the duplicate diet and diet records were collected, the diet was homogenized using deionized water, the total volume was measured and an aliquot sample of $50 \mathrm{~mL}$ was taken and frozen $\left(-20^{\circ} \mathrm{C}\right)$ until analysis.

\section{Determination of fluoride intake from dentifrice}

This was carried out as described by GuhaChowdhury et al. ${ }^{9}$. Attempts were made to simulate real home-use conditions by replicating whether the parents or the children performed the brushing, the size of the toothbrush used, how much dentifrice was spread on the brush, whether the parents or the children applied the dentifrice to the brush, whether the children expectorated after brushing and the length of time spent brushing. The parents were asked to bring a new toothbrush similar in size to the one that the children normally used to brush. The dentifrice was supplied by the researchers (Sorriso, 1,570 ppm F w/ w as MFP), because the present study was part of a bigger study, involving the influence of dentifrice and fluoridated varnish on urine and nail $\mathrm{F}$ concentrations. New toothbrush was weighed $( \pm 0,1 \mathrm{mg})$. Dentifrice was spread on the toothbrush by the parents or children, and the weight of the toothbrush plus dentifrice was recorded. This provided information on the amount of $\mathrm{F}$ loaded onto the brush. Brushing was performed by the children with or without the assistance of the parents and under the observation of the examiner. Depending on the home habits, the children were allowed to expectorate or not and to rinse or not. The expectorant was collected in a 
weighed, plastic, wide-mouth vessel and analyzed for F. The toothbrush was thoroughly rinsed in known volumes of deionized water, and the rinse was analyzed for $\mathrm{F}$ to determine the amount of $\mathrm{F}$ left on the toothbrush. The amount of $\mathrm{F}$ left on the toothbrush and the amount expelled were added, to give the total amount of $\mathrm{F}$ expelled and not swallowed. The amount of $F$ ingested was then indirectly derived, by subtracting the amount of $\mathrm{F}$ expelled from the amount initially loaded onto the toothbrush. Information on frequency of brushing was obtained and used to calculate the daily $\mathrm{F}$ intake from dentifrice for each child. At this day, the children were also weighed.

\section{Fluoride Analysis}

Fluoride concentration in the diet and dentifrice samples were determined after overnight, hexamethyldisiloxane (HMDS)-facilitated diffusion ${ }^{22}$ as modified by Whitford ${ }^{25}$ using a fluoride ion-specific electrode (Orion Research, Cambridge, Mass., USA, model 9409) and a miniature calomel reference electrode (Accumet, \#13-620-79), both coupled to a potentiometer (Orion Research, model EA 940). During the diffusion process, which was conducted at room temperature, the solutions in the non-wettable Petri dishes (Falcon, No. 1007) were gently swirled on a rotatory shaker. Fluoride standards $(0.0095,0.019$, 0.095 and $0.190 \mu \mathrm{g} \mathrm{F}$ ) were prepared by serial dilution of a stock-standard containing $0.1 \mathrm{M}$ of Fluoride (Orion 940906) in triplicate and diffused in the same manner as the samples. In addition, nondiffused fluoride standards were prepared with the same solutions ( $0.05 \mathrm{M} \mathrm{NaOH}, 0.20 \mathrm{M}$ acetic acid, plus $\mathrm{NaF}$ ) that were used to prepare the diffused standards and samples. The nondiffused standards were made up to have exactly the same fluoride concentrations as the diffused standards. Comparison of the millivolt readings demonstrated that the fluoride in the diffused standards had been completely trapped and analyzed. The millivoltage potentials were converted to $\mu \mathrm{g} \mathrm{F}$ using a standard curve with a coefficient correlation of $r^{3} 0.99$. All samples were analyzed in duplicate.

\section{Statistical analysis}

The data are expressed as mean \pm SD. Data were analyzed for statistically significant differences by Student's " $\mathrm{t}$ " test $(\mathrm{p}<0.05)$ and by linear regression $(\mathrm{p}<0.0001)$.

\section{RESULTS}

Table 1 shows the amount of dentifrice used, as well as the amount and percentage of dentifrice ingested from brushing. Group B used more dentifrice $(0.48 \pm 0.35 \mathrm{~g})$ than Group A $(0.38 \pm 0.17 \mathrm{~g})$, but this difference was not statistically significant $(\mathrm{t}=0.7979$, $p=0.435)$. The percentage of $F$ ingested was smaller for Group B $(32.25 \pm 18.23 \%)$, when compared to Group A $(36.11 \pm 22.01 \%)$ although the difference was not significant.

Table 2 shows the $\mathrm{F}$ intake from the diet, dentifrice and total (diet plus dentifrice), in a period of 24 hours. It was observed that $33.3 \%$ of the children were exposed to a $\mathrm{F}$ dosage above the maximum total desirable fluoride intake per day $(0.07 \mathrm{mg} \mathrm{F} / \mathrm{kg}$ body weight/day) ${ }^{3}$. In addition, 3 children exceeded the maximum total desirable fluoride intake considering only $\mathrm{F}$ ingested from dentifrice.

Group A had a mean $\mathrm{F}$ intake from dentifrice smaller than Group B. However, with respect to the diet, the reverse occurred. In both situations, the differences between the two groups were not statistically significant $(\mathrm{t}=0.4037, \mathrm{p}=0.692$; and $\mathrm{t}=$ $0.9503, p=0.356$ for dentifrice and diet, respectively).

The contribution of dentifrice to the daily $\mathrm{F}$ intake was another important find. As seen in Table 2 and Figure 1, mean daily $\mathrm{F}$ intake from dentifrice was 2fold greater than $\mathrm{F}$ intake from the diet. This difference between the two sources of $\mathrm{F}$ was more pronounced in Group B. A strong positive correlation was found between the amount of $\mathrm{F}$ placed on the brush and the amount ingested (Figure 2, $\mathrm{r}=0.92, \mathrm{p}<0.0001$ ).

\section{DISCUSSION}

In the present study, the main source of $\mathrm{F}$ intake by children was the dentifrice $(57.43 \%$ of the total $\mathrm{F}$ intake). A similar finding, despite for a different age range, was reported by Lima and Cury ${ }^{13}$ who found that the dentifrice contributed with $55 \%$ of the total

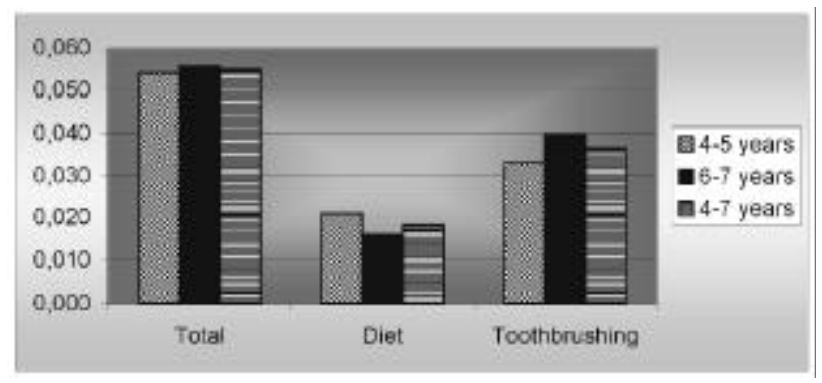

FIGURE 1- Daily fluoride intake ( $\mathrm{mg} / \mathrm{kg}$ body weight) from diet, dentifrice and total 
daily $\mathrm{F}$ intake of 2-3 year-old Brazilian children. Ideally, $\mathrm{F}$ present in dentifrices should have only topical effects action, aiming to reduce demineralization and/or enhance enamel remineralization. However, our data confirm other studies in the literature $1,3,4,13,17,24$ and show that there is a considerable amount of $\mathrm{F}$ exposure systemically. Thus, the use of fluoridated dentifrices by many children is an important risk factor for development of dental fluorosis.

The percentage of $\mathrm{F}$ ingestion with each brushing varied between 0 and $76.03 \%$ of the amount of $F$ applied to the brush, averaging $34.09 \%$ for all children. Some of the children exceeded the maximum total desirable fluoride intake per day, considering only $\mathrm{F}$ ingested from dentifrice. Despite the fact that this happened for only $14 \%$ of the children studied, this finding is of concern especially when the F intake from other sources is considered.

The literature has shown that the $\mathrm{F}$ intake from dentifrice is inversely related to age, it being higher for younger children ${ }^{20}$. In the present study it was observed that the percentage of $F$ ingested was higher for Group A (4-5 year-olds). However, the total amount of $F$ ingested was higher for Group B (6-7 year-olds), since the amount of dentifrice loaded onto the brush was higher for these children. These differences, however, were small and not significant.

TABLE 1- Use and ingestion of dentifrice of 4-7-year-old children, using a fluoride dentifrice (SorrisoÒ, 1570 ppm F, MFP)

\begin{tabular}{|c|c|c|c|c|c|}
\hline Children & $\begin{array}{c}\text { Age* }^{*} \\
\text { (years) }\end{array}$ & $\begin{array}{l}\text { Amount of dentifrice } \\
\text { loaded onto } \\
\text { the brush }(g)\end{array}$ & $\begin{array}{l}\text { Amount of fluoride } \\
\text { loaded onto } \\
\text { the brush }(\mathrm{g})\end{array}$ & $\begin{array}{l}\text { Amount of fluoride } \\
\text { ingested by } \\
\text { brushing }(\mu \mathrm{g})\end{array}$ & $\begin{array}{c}\% \text { of fluoride } \\
\text { ingested }\end{array}$ \\
\hline 1 & $4-5$ & 0.54 & 0.71 & 0.410 & 57.58 \\
\hline 2 & $4-5$ & 0.43 & 0.57 & 0.191 & 33.69 \\
\hline 3 & $4-5$ & 0.22 & 0.29 & 0.031 & 10.67 \\
\hline 4 & $4-5$ & 0.43 & 0.57 & 0.199 & 33.69 \\
\hline 5 & $4-5$ & 0.23 & 0.30 & 0.132 & 43.56 \\
\hline 6 & $4-5$ & 0.12 & 0.16 & 0.041 & 25.32 \\
\hline 7 & $4-5$ & 0.40 & 0.63 & 0.479 & 76.03 \\
\hline 8 & $4-5$ & 0.63 & 0.99 & 0.480 & 48.48 \\
\hline 9 & $4-5$ & 0.54 & 0.85 & 0.273 & 32.12 \\
\hline 10 & $4-5$ & 0.25 & 0.39 & 0.000 & 0.00 \\
\hline 11 & $6-7$ & 0.58 & 0.77 & 0.243 & 32.29 \\
\hline 12 & $6-7$ & 0.32 & 0.42 & 0.143 & 33.89 \\
\hline 13 & $6-7$ & 0.44 & 0.58 & 0.293 & 57.24 \\
\hline 14 & $6-7$ & 0.20 & 0.26 & 0.047 & 17.80 \\
\hline 15 & $6-7$ & 0.49 & 0.77 & 0.170 & 22.08 \\
\hline 16 & $6-7$ & 0.08 & 0.13 & 0.000 & 0.00 \\
\hline 17 & $6-7$ & 0.20 & 0.32 & 0.043 & 13.44 \\
\hline 18 & $6-7$ & 1.07 & 1.69 & 0.688 & 40.71 \\
\hline 19 & $6-7$ & 1.04 & 1.64 & 0.928 & 56.59 \\
\hline 20 & $6-7$ & 0.09 & 0.14 & 0.043 & 30.43 \\
\hline 21 & $6-7$ & 0.73 & 1.15 & 0.573 & 50.26 \\
\hline Mean & $4-5$ & 0.38 & 0.55 & 0.224 & 36.11 \\
\hline SD & $4-5$ & 0.17 & 0.26 & 0.182 & 22.01 \\
\hline Mean & $6-7$ & 0.48 & 0.72 & 0.288 & 32.25 \\
\hline SD & $6-7$ & 0.35 & 0.56 & 0.308 & 18.23 \\
\hline Mean & $4-7$ & 0.43 & 0.63 & 0.257 & 34.09 \\
\hline SD & $4-7$ & 0.28 & 0.44 & 0.252 & 19.70 \\
\hline
\end{tabular}

* Groups A and B are constituted by children aging 4-5 and 6-7- year-old children, respectively. 
An important finding in this study was the strong positive correlation between the amount of dentifrice placed on the toothbrush and the amount of $\mathrm{F}$ ingested. Thus, the first method to diminish the amount of $\mathrm{F}$ ingested from dentifrice should be to reduce the amount of dentifrice loaded onto the toothbrush. This measure is important and could be efficient, when combined with educational process directed to the parents. However, this may not be easily accomplished because, nowadays, in most families both parents work and people who take care of the children do not always follow parents' instructions. In addition, the pleasant flavor of most of the infant dentifrices probably encourages the use of large amounts of dentifrice and its ingestion.
Due to these problems, it has been proposed that dentifrices with lower $\mathrm{F}$ concentrations should be developed and marketed for use by young children, as has been done in many countries ${ }^{1,11}$, including Brazil, where a $500 \mathrm{ppm} F$ dentifrice was recently introduced in the market.

There have been many longitudinal clinical trials of the effectiveness of dentifrices with lower fluoride concentrations. Some of them found no significant differences between standard (1,000-1,100 ppm) and low fluoride dentifrices (250-550 ppm fluoride) $)^{7,8,11}$. In contrast, Reed ${ }^{19}$, Mitropoulos and co-workers ${ }^{16}$ and Koch and co-workers ${ }^{12}$ found the low-fluoride dentifrices to be somewhat less effective than the 1,000

TABLE 2- Daily F intake from diet, dentifrice and total of 4-7-year-old children, living in Bauru

\begin{tabular}{|c|c|c|c|c|c|c|c|c|}
\hline Children & $\begin{array}{l}\text { Age }^{*} \\
\text { (years) }\end{array}$ & $\begin{array}{l}\text { Dentifrice } \\
\text { (mg) }\end{array}$ & $\begin{array}{l}\text { Diet } \\
(\mathrm{mg})\end{array}$ & $\begin{array}{l}\text { Total } \\
(\mathrm{mg})\end{array}$ & $\begin{array}{c}\text { Body } \\
\text { weight } \\
\text { (kg) }\end{array}$ & $\begin{array}{l}\text { Dentifrice F } \\
\quad \text { intake } \\
\text { (mg/kg/day) }\end{array}$ & $\begin{array}{c}\text { Diet F } \\
\text { intake } \\
\text { (mg/kg/day) }\end{array}$ & $\begin{array}{c}\text { Total F intake } \\
\text { (mg/kg/day) }\end{array}$ \\
\hline 1 & $4-5$ & 1.230 & 0.342 & 1.572 & 19.0 & 0.065 & 0.018 & 0.083 \\
\hline 2 & $4-5$ & 0.573 & 0.484 & 1.057 & 15.0 & 0.038 & 0.032 & 0.070 \\
\hline 3 & $4-5$ & 0.155 & 0.594 & 0.749 & 20.0 & 0.008 & 0.030 & 0.037 \\
\hline 4 & $4-5$ & 0.796 & 0.031 & 0.827 & 18.0 & 0.044 & 0.002 & 0.046 \\
\hline 5 & $4-5$ & 0.396 & 0.459 & 0.855 & 24.7 & 0.016 & 0.019 & 0.035 \\
\hline 6 & $4-5$ & 0.123 & 0.067 & 0.190 & 22.0 & 0.006 & 0.003 & 0.009 \\
\hline 7 & $4-5$ & 1.437 & 0.313 & 1.750 & 22.0 & 0.065 & 0.014 & 0.080 \\
\hline 8 & $4-5$ & 1.440 & 0.309 & 1.749 & 20.0 & 0.072 & 0.015 & 0.087 \\
\hline 9 & $4-5$ & 0.546 & 1.350 & 1.896 & 30.0 & 0.018 & 0.045 & 0.063 \\
\hline 10 & $4-5$ & 0.000 & 0.602 & 0.602 & 19.0 & 0.000 & 0.032 & 0.032 \\
\hline 11 & $6-7$ & 0.729 & 0.624 & 1.353 & 18.5 & 0.039 & 0.034 & 0.073 \\
\hline 12 & $6-7$ & 0.429 & 0.652 & 1.081 & 22.0 & 0.020 & 0.030 & 0.049 \\
\hline 13 & $6-7$ & 1.172 & 0.421 & 1.593 & 24.6 & 0.048 & 0.017 & 0.065 \\
\hline 14 & $6-7$ & 0.188 & 0.286 & 0.474 & 20.0 & 0.009 & 0.014 & 0.024 \\
\hline 15 & $6-7$ & 0.680 & 0.182 & 0.862 & 32.5 & 0.021 & 0.006 & 0.027 \\
\hline 16 & $6-7$ & 0.000 & 0.220 & 0.220 & 20.3 & 0.000 & 0.011 & 0.011 \\
\hline 17 & $6-7$ & 0.129 & 0.317 & 0.446 & 31.5 & 0.004 & 0.010 & 0.014 \\
\hline 18 & $6-7$ & 2.064 & 0.388 & 2.452 & 22.0 & 0.094 & 0.018 & 0.111 \\
\hline 19 & $6-7$ & 2.784 & 0.486 & 3.270 & 18.0 & 0.155 & 0.027 & 0.182 \\
\hline 20 & $6-7$ & 0.086 & 0.088 & 0.174 & 27.0 & 0.003 & 0.003 & 0.006 \\
\hline 21 & $6-7$ & 1.146 & 0.137 & 1.283 & 25.0 & 0.046 & 0.005 & 0.051 \\
\hline Mean (SD) & $4-5$ & $\begin{array}{l}0.670 \\
(0.540)\end{array}$ & $\begin{array}{l}0.455 \\
(0.369)\end{array}$ & $\begin{array}{l}1.125 \\
(0.580)\end{array}$ & $\begin{array}{l}21.0 \\
(4.1)\end{array}$ & $\begin{array}{l}0.034 \\
(0.027)\end{array}$ & $\begin{array}{l}0.021 \\
(0.014)\end{array}$ & $\begin{array}{l}0.055 \\
(0.026)\end{array}$ \\
\hline Mean (SD) & $6-7$ & $\begin{array}{l}0.855 \\
(0.888)\end{array}$ & $\begin{array}{l}0.346 \\
(0.188)\end{array}$ & $\begin{array}{l}1.201 \\
(0.963)\end{array}$ & $\begin{array}{l}23.8 \\
(4.9)\end{array}$ & $\begin{array}{l}0.040 \\
(0.046)\end{array}$ & $\begin{array}{l}0.016 \\
(0.010)\end{array}$ & $\begin{array}{l}0.057 \\
(0.052)\end{array}$ \\
\hline Mean (SD) & $4-7$ & $\begin{array}{l}0.767 \\
(0.731)\end{array}$ & $\begin{array}{l}0.398 \\
(0.287)\end{array}$ & $\begin{array}{l}1.164 \\
(0.785)\end{array}$ & $\begin{array}{l}22.4 \\
(4.7)\end{array}$ & $\begin{array}{l}0.037 \\
(0.038)\end{array}$ & $\begin{array}{l}0.018 \\
(0.012)\end{array}$ & $\begin{array}{l}0.056 \\
(0.040)\end{array}$ \\
\hline
\end{tabular}

* Groups A and B are constituted by children aging 4-5 and 6-7- year-old children, respectively. 
ppm dentifrices.

At first glance, these studies might suggest that lowfluoride dentifrices are less effective in terms of caries prevention than standard $1,000 \mathrm{ppm}$ dentifrices. However, of these studies, only one ${ }^{8}$ was conducted on the appropriate, preschool age group. This study did not find a statistically significant difference between $250 \mathrm{ppm}$ and 1,000 ppm dentifrices. In view of the negative results of the studies cited above, however, it may be that a fluoride concentration of $250 \mathrm{ppm}$ is too much of a departure from the standard $1,000 \mathrm{ppm}$ dentifrice. A more practical formulation may have fluoride concentrations in the range of 500$550 \mathrm{ppm}^{24}$.

The only study of low-fluoride dentifrice that used both a sample of young, preschool children and a 500$550 \mathrm{ppm}$ dentifrice was reported by Winter and coworkers ${ }^{26}$. This three-year, double blind trial compared effectiveness of 550 and 1,055 ppm fluoride dentifrices in children who were two years of age at baseline by measuring $\mathrm{dmf}$ increments. The caries increment was slightly higher $(10 \%)$ in the low-fluoride dentifrice group after three years, but the difference was not statistically significant.

Despite some uncertainty about the anti-caries effect of low-F concentration dentifrices ${ }^{24}$, the European Academy of Paediatric Dentistry recommends the use of a very small amount of low-F concentration dentifrice from 6 months to 2 years of age and the use of a pea-sized amount of $500 \mathrm{ppm} \mathrm{F}$ twice daily from 2 to 6 years. A higher fluoride concentration dentifrice (1,000-1,500 ppm) should be used as soon as the first permanent molars erupt ${ }^{17}$. We agree with these recommendations.

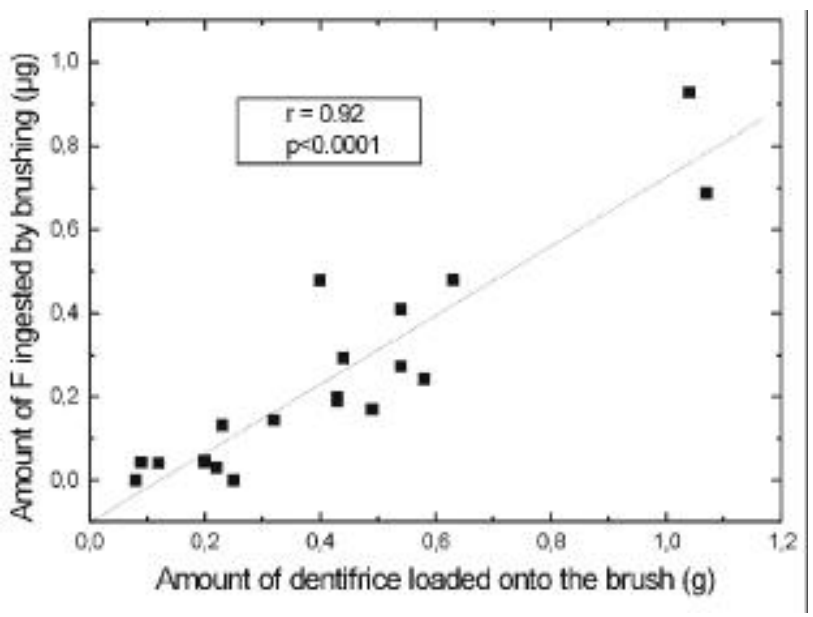

FIGURE 2- Correlation between the amount of dentifrice loaded onto the brush and the amount ingested

\section{RESUMO}

Este estudo analisou a ingestão total diária de flúor de 21 crianças, residentes numa comunidade fluoretada. A ingestão de flúor $(\mathrm{F})$ através da dieta (D) e dentifrício (B) foi determinada para 2 grupos de crianças: A (4-5 anos de idade) e B (6-7 anos de idade). O método da dieta duplicada (24 horas) foi utilizado. $\mathrm{O} F$ ingerido a partir do dentifrício foi indiretamente derivado, subtraindo-se a quantidade expelida e a quantidade que restou na escova da quantidade inicialmente colocada na escova. A análise de F foi feita com o eletrodo íon-específico (Orion 9409), após difusão facilitada por hexametil-disiloxano. A quantidade de $\mathrm{F}$ ingerida a partir de $\mathrm{D}$ e $\mathrm{B}$ foi dividida pelo peso da criança e a ingestão total (T) foi calculada adicionando-se $\mathrm{D}$ e B. Os dados foram analisados pelo teste " $t$ " de Student $(p<0,05)$ e por regressão linear. Os resultados (média \pm desvio padrão, $\mathrm{mg}$ F/Kg peso corporal) de T, D e B foram, respectivamente: $0,056 \pm 0,040 ; 0,018 \pm 0,012 ; 0,037 \pm 0,038$ para todas as crianças, $0,055 \pm 0,026 ; 0,021 \pm 0,014 ; 0,034 \pm 0,027$ para o grupo A e $0,057 \pm 0,052 ; 0,016 \pm 0,010 ; 0,041 \pm 0,046$ para o grupo B. Foi observada uma forte correlação positiva entre a quantidade de dentifrício usada e a quantidade de $\mathrm{F}$ ingerida $(\mathrm{r}=0,92, \mathrm{p}<0,0001)$. Um terço das crianças analisadas estão expostas a uma dose de $\mathrm{F}$ acima de $0,07 \mathrm{mg} / \mathrm{Kg}$ de peso corporal, que é considerada o limite máximo de ingestão diária de $\mathrm{F}$. $\mathrm{O}$ dentifrício foi a principal fonte de flúor ingerida pelas crianças, com percentuais de 57,43 $\pm 29,02$ para todas as crianças, $56,49 \pm 31,82$ para o grupo A e $58,29 \pm 27,78$ para o grupo B. Não foram encontradas diferenças significantes entre os dois grupos.

UNITERMOS: Flúor; Fluorose dentária; Dentifrício; Dieta.

\section{ACKNOWLEDGEMENTS}

This work was supported by FAPESP (Grants $n^{\circ}$ 00/04303-8 and 01/00237-3).

\section{REFERENCES}

1- Beltran ED, Spuznar SM. Fluoride in toothpastes for children: suggestions for change. Pediatr Dent 1998; 10:185-8.

2- Brunetti A, Newbrun E. Fluoride balance of children 3 and 4 years old. Caries Res 1983; 17(2): 171. 
3- Burt BA. The changing patterns of systemic fluoride intake. J Dent Res 1992; 71: 1228-37.

4- Buzalaf MAR, Cury JA, Whitford GM. Fluoride exposures and dental fluorosis: a literature review. Rev Fac Odontol Bauru 2001; 9(1/2):1-10.

5- Buzalaf MAR, Granjeiro JM, Duarte JL, Taga MLL. Fluoride content of infant foods in Brazil and risk of dental fluorosis. J Dent Child 2002; 69(2): 196-200.

6- Clark DC. Trends in prevalence of dental fluorosis in North America. Comm Dent Oral Epidemiol, 1994; 22:148-52.

7- Forsman B. Studies on the effect of dentifrices with low fluoride content. Comm Dent Oral Epidemiol 1974; 2(4): 166-75

8- Gerdin P. Studies in dentifrices, VIII: Clinical testing of an acidulated, nongriding dentifrice with reduced fluoride contents. Swed Dent J 1974; 67(5): 283-97.

9- Guha-Chowdhury N, Drummond BK, Smillie AC. Total fluoride intake in children aged 3 to 4 years - a longitudinal study. J Dent Res 1996; 75(7):1451-7.

10- Ishii T, Suckling G. The severity of dental fluorosis in children exposed to water with a high fluoride content for various periods of time. J Dent Res 1991; 70:952-6.

11- Koch G, Petersson LG, Kling E, Kling L. Effect of 250 and $1000 \mathrm{ppm}$ fluoride dentifrice on caries. A three-year clinical study. Swed dent J 1982; 6(6):233-8.

12- Koch G, Gergmann-Arnadottir I, Bjarnason S, Finnbogason S, Hoskuldsson O, Karlsson R. Caries-preventive effect of fluoride dentifrices with and without anticalculus agents: a 3-year controlled clinical trial. Caries Res 1990; 24(1): 72-9.

13- Lima YBO, Cury JA. Ingestão de flúor por crianças através da água e dentifrício. Rev. Saúde Publica 2001; 35: 576-81.

14- Mascarenhas, A.K. Risk factors for dental fluorosis: a review of the recent literature. Pediatr Dent 2000; 22(4): 269-77.

15- McClure F.J. Ingestion of fluoride and dental caries, quantitative relations based on food and water requirements of children 1 to 12 years old. Am J Dis Chil 1943;66: 362-9.

16- Mitropoulos CM, Holloway PJ, Davies TG, Worthington HV. Relative efficacy of dentifrices containing 250 or 1000 ppm F in preventing dental caries - report of a 32-month clinical trial. Comm Dent Hlth 1984; 1(3): 193-200.

17- Oulis C, Raadal M, Martens L. Guidelines on the use of fluoride in children: An EAPD policy document. Eur J Paediatr Dent 2000; $1: 7-12$.

18- Paiva SM, Cury JA. Dentifrício fluoretado e risco de fluorose dentária. Rev Pós Grad; 2003 (no prelo).

19- Reed MW. Clinical evaluation of three concentrations of sodium fluoride in dentifrices. J Am Dent Ass 1973; 87(7): 14013.
20- Richards A, Banting DW. Fluoride toothpastes. In: Fejerskov $\mathrm{O}$, Burt BA, editors. Fluoride in dentistry. Copenhagen, Munksgaard, 1996. p.328-46.

21- Rojas-Sanchez F, Kelly SA, Drake KM, Eckert GJ, Stookey GK, Dunipace AJ. Fluoride intake from foods, beverages and dentifrice by young children in communities with negligible and optimally fluoridated water: a pilot study. Comm Dent Oral Epidemiol 1999; 27(4): 288-97.

22- Taves OR. Separation of fluoride by rapid diffusion using hexamethyldisiloxane. Talanta, 1968; 15:969-74.

23- US Public Health Service. Ad Hoc Subcommittee on Fluoride. Review on fluoride: benefits and risks. Washington, D.C., Department of Health and Human Services, 1991.

24- Warren JJ, Levy SM. A review of fluoride dentifrice related to dental fluorosis. Pediatr Dent 1999; 21(4):265-71.

25- Whitford GM. Absorption and plasma concentrations of fluoride. In: The metabolism and toxicity of fluoride. Monographs in Oral Science, 1996; 16:24-9.

26- Winter GB, Holt HD, Williams BF. Clinical trial of a lowfluoride toothpaste for young children. Int Dent J 1989; 39(4): 227-35.

Recebido para publicação em: 10/03/2003

Aceito após reformulações em: 05/05/2003

Correspondence Address:

Marília Afonso Rabelo Buzalaf

Al. Octávio Pinheiro Brisolla, 9-75

Bauru-SP

Brasil

17012-901

e-mail: mbuzalaf@fob.usp.br 